\title{
Demographical Analysis and Cultural Characteristic to Attract Japanese Tourists to Indonesia
}

\author{
Agita Arrasy Asthu'*; William Kalua Putra² \\ ${ }^{1,2}$ Ministry of Tourism and Creative Economy Republic of Indonesia \\ Jln. Medan Merdeka Barat No.17, Jakarta Pusat 10110, Indonesia \\ 1agitarrasy@gmail.com; ${ }^{2}$ william@indonesia.travel
}

Received: $9^{\text {th }}$ November 2020/ Revised: $24^{\text {th }}$ November 2020/ Accepted: $2^{\text {nd }}$ February 2021

How to Cite: Asthu, A. A., \& Putra, W. K. (2021). Demographical Analysis and Cultural Characteristic to Attract Japanese Tourists to Indonesia. Binus Business Review, 12(3), 231-239. https://doi.org/10.21512/bbr.v12i3.6789

\begin{abstract}
Japan is one of the biggest international tourist contributors to Indonesia. However, in recent years, there is a negative growth. It is caused by the demographical change of the Japanese population and outbound. Hence, research about the cultural ethnicity and social conditions affecting international travelers' behavior in tourism activities is needed. The research focused on the segmentation and strategies to attract foreign tourist which Indonesia would carry. The applied research method was a qualitative descriptive approach that utilized secondary data, such as demographical data and cultural characteristics. Data were taken from the Central Bureau of Statistics of the Republic of Indonesia, Ministry of Tourism and Creative Economy of the Republic of Indonesia, World Bank, and Statistics Bureau of Japan. Then, those data were analyzed by a descriptive statistics method. The result intends to formulate a strategy to seek more potential tourist growth from a Japanese market. The result shows four strategic efforts that Indonesia can take to maximize the potential for the arrival of foreign tourists from Japan. The government can consider the increased number of "silver age" and adult female workers (Joshitabi), which dominate the travelers' segment to Indonesia, and pay attention to air connectivity and unique cultural characteristic of Japan.
\end{abstract}

Keywords: demographical analysis, cultural characteristic, Japanese tourists

\section{INTRODUCTION}

Compared to other sources of state income in Indonesia, tourism is the top three largest foreign exchange-earners, under Crude Palm Oil (CPO) and coal (Bank Indonesia, 2018). However, it is believed that in the next few years, natural resources, which are constantly exploited, will show a negative growth trend in line with the decrease in reserve resources. On the contrary, tourism has the opportunity to continue to expand and outperform other sources of foreign exchange. The sustainable growth characteristic of the tourism sector is a strength and advantage that other sectors do not have. Currently, tourism is the fastestgrowing economic activity. It is responsible for the success of economic growth (Mendola \& Volo, 2017). The simplest thing is to look at the number of visits and the growth data of foreign tourists to measure the success of one country's tourism. There is a correlation between the length of time and expenses that foreign tourists spend at their destination (Marrocu, Paci, \& Zara, 2015). The implication of the arrival of foreign tourists will greatly affect the amount of foreign exchange that the country gets.

International tourists travel by staying in a country that is not their residence, for more than 24 hours, but not more than one year. Moreover, they do not have any intention of seeking a source of income from the destination country (Asthu, 2020). Therefore, it is assumed that they are interested in traveling and search for unusual or different experiences outside of routine (Moon \& Han, 2019; Subadra, Sutapa, Artana, Yuni, \& Sudiarta, 2019).

Several factors influence traveling, such as distance (Artal-Tur, Pallardó-López, \& RequenaSilvente, 2016; Mariyono, 2017; Mishra \& Bansal, 2017), cost (Moon \& Han, 2019; Chhorn, 2017; Utama, 2016), assessment over the destination (Battour, Hakimian, Ismail, \& Boğan, 2018; Liu, Li, \& Kim, 2017), infrastructure support, availability 
of various attractions, climate (Jayaprakash, 2016; Yusup, Kanyan, Kasuma, Kamaruddin, \& Adli, 2016), visa requirements, flight availability, and security at the destination (Liu, Wang, Fang, \& Zhang, 2019). Apart from the factors that motivate tourists to visit a destination, there are also several external factors, such as destination marketing (Liu, Pan, \& Zheng, 2019; Sukirman, 2017) and policies issued by the destination countries (Artal-Tur et al., 2016; Mylonopoulos, Moira, \& Kikilia, 2016; Ob \& Mp, 2018).

Data from Badan Pusat Statistik (2020) mentioned that foreign tourists in 2019 reached 16.106.954 international arrivals. Around 32,5\% came from the Asia Pacific Region, such as China, Taiwan, Hong Kong, Australia, Japan, South Korea, and India. The Asia Pacific Region was the second-largest source of foreign tourists in Indonesia after Southeast Asia in 2019. Behind the large contribution of the Asia Pacific Region to the number of foreign tourists, it is found that the growth in 2019 is negative compared to the previous year (Badan Pusat Statistik, 2019). Four of the seven countries in the Asia Pacific Region with negative growth are Taiwan $(-0,40 \%)$, Hong Kong $(-44,81 \%)$, Japan $(-2,06 \%)$, and China $(-3,14 \%)$ (Badan Pusat Statistik, 2019).

With an area of $377.972 \mathrm{~km}^{2}$ and a total population of 126 million people (Statistics Bureau of Japan, 2019), Japan is one of the countries with the largest economic growth in the world. Even its total of Gross Domestic Product (GDP) in 2018 became the third-largest after the United States and China, amounting to US\$4,971 trillion (The World Bank, 2020). In the release of the Travel and Tourism Competitiveness Index, a report on the competitiveness of tourism destinations, Japan was ranked fourth out of a total of 140 countries (World Economic Forum, 2019b). In comparison, Indonesia was ranked 40. Moreover, Japanese tourists are promising quality tourists, as proven by their average daily expense of US $\$ 180,25$ and an average length of stay of seven days per trip. The shown data are significantly bigger than the total of average international travelers' daily spending in Indonesia, which is about US\$142,67 (Kementerian Pariwisata dan Ekonomi Kreatif Republik Indonesia, 2019).

In Indonesia, Japan was the seventh-largest contributor to foreign tourists in 2019, amounting to 519.623 visits (Badan Pusat Statistik, 2020). Moreover, Japan is one of the largest tourist-producing countries in the world. Japanese tourists are widely known to spend more for shopping. They spend around 36,2\% of the total travel costs for shopping, and most are spent on food (Kim, Timothy, \& Hwang, 2011). However, the growth number is not as favorable as its contribution towards the international tourists' arrival to Indonesia.

The demand for Japanese outbound travelers has more than doubled over the 1990 s period. A booming economy, lifestyle changes, and a stronger Yen contribute to the demand for travel outside Japan (Kamata \& Misui, 2015; Kim, Lee, \& Mjelde, 2018;
Lim \& McAleer, 2005). This period becomes the forerunner of the Japanese outbound, which is now in demand by many destinations. Of course, many typologies have been created to understand the product preferences, motives, and behavior or experiences related to tourists' visits to a destination (Kim, Park, \& Lamb, 2019; Kim et al., 2011). For example, different types of products must be provided depending on the level of education, socioeconomic status, age, and others. Moreover, Japanese tourists also prioritize quality, service safety, and clarity of information (Yu \& Ko, 2012).

The research aims to confirm that the cultural ethnicity and social conditions affect the behavior of international travelers in tourism activities, especially for travelers coming from Japan, China, and Korea who have similarities in product preferences (Kim et al., 2011; Yu \& Ko, 2012). From most of the research, Japanese culture has a collective nature in which the Japanese tourists tend to get some gifts for the family in origination and have empathy. They are also very dependent on a sense of security and security, passive, more masculine, and very fond of photography. However, they also demand hierarchical status, require evidence from a destination, avoid risks, and tend to save and long-term orientation (Kim et al., 2011; Williams, Soutar, Ashill, \& Naumann, 2017; Yeung, Kim, \& Schuckert, 2016). The largest segment of Japanese tourists $(40,5 \%)$ prioritizes nature, food, and leisure. This segment consists mostly of women aged 50-79 (Kamata \& Misui, 2015).

It has proven that there is a gap between Japanese tourists coming to Indonesia's tourism performance to the fact of Japanese economic competitiveness and excellent quality of Japanese tourists. Therefore, Indonesia is urged to be aware of the ever-developing market condition. Based on this, the research concentrates on the segmentation and strategies to attract foreign tourists which Indonesia will carry on.

The research utilizes demographical data as its analytical basis. The importance of specific information towards the demographic profile of potential tourists enables better planning for industry and destination as a whole (Sinclair-Maragh, 2017). Therefore, the demographical variable needs to be studied to understand the market perception of strategic tourism marketing development (Sinclair-Maragh, Gursoy, \& Vieregge, 2015). Each demographical object has its unique characteristics which require different approaches towards them. Even each gender and age group have their characteristics when traveling (Sinclair-Maragh, 2017).

Apart from it, the research sees the importance of understanding cultural backgrounds as one of the strategies for tourism marketing and planning (Dai, Hein, \& Zhang, 2019; Kumar \& Dhir, 2020; Fernández, Azevedo, Martín, \& Martín, 2020). Culture represents the accumulation of behavioral patterns in society and different macro-environment elements. Then, those affect different behavioral patterns (Scupin, 2020). As 
a result, each culture has its different characteristics and must be studied thoroughly to get a clear image to plan a good tourism marketing strategy.

Addressing the problem mentioned earlier, the research question is around the development of the tourism potential of the Japanese market through demographical data and cultural background. As for the research limitation, the research includes the potential of the Japanese tourism market which is obtained from demographical data and cultural background analysis. It is intended to be a recommendation for tourism stakeholders and is expected to bring more Japanese travelers in the future. Therefore, subjects outside the ever mentioned are not the focus of the research.

\section{METHODS}

The research applies a qualitative approach method. Then, the analytical method is descriptive statistics. The methods describe circumstances and conditions by utilizing numbers and words from sources such as variables and circumstances demographics without testing hypotheses (Zellatifanny \& Mudjiyanto, 2018). Hence, the data are secondary. The data utilizes the available and processed information according to the research needs (Asthu, 2020). The data are the number of foreign tourist visits from the Central Bureau of Statistics of the Republic of Indonesia, the characteristics of tourists from the Ministry of Tourism and Creative Economy of the Republic of Indonesia, GDP and outbound expenditures from the World Bank, and demographics and welfare figures from the Statistics Bureau of Japan.

\section{RESULTS AND DISCUSSIONS}

The number of Japanese populations in 2018 was decreased by 276.000 people or $0,2 \%$ from the previous year. The negative population growth had occurred for nine consecutive years. The composition in 2018 was 61.411 .000 or $48,7 \%$ men and 64.756 .000 or $51,3 \%$ women. Japan is the country with the highest life expectancy in the world. A total of $28,4 \%$, or nearly one-third of Japan's population, has a total population aged over 65 years (Statistics Bureau of Japan, 2019). Japan can achieve high life expectancy thanks to the quality of life, which is supported by qualified health facilities (World Economic Forum, 2019a). Figure 1 shows the Japanese population pyramid.

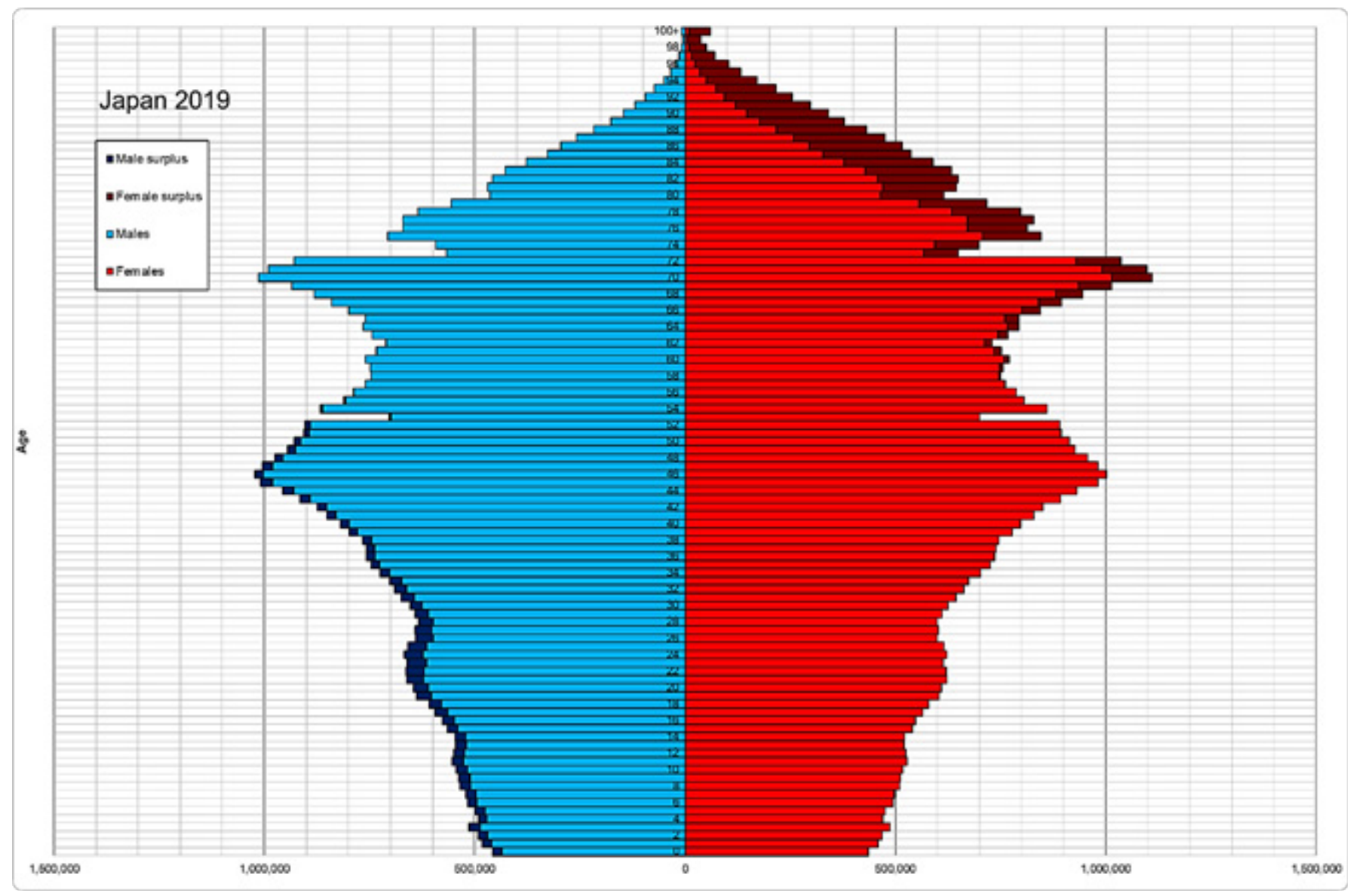

Figure 1 The Japanese Population Pyramid (Source: Statistics Bureau of Japan, 2019) 
The growing number of senior citizens in Japan will continue to increase over time. Coupled with the fertility rate, which tends to decline from time to time, it is predicted that Japan will have a cohort of 65 years and over in 2060 with $38,1 \%$ of the total population (see Figure 2). By the end of 2060, it is predicted that Japan will experience a decrease in the quantity of the productive workforce. On the other hand, the number of pensioners or the "silver age" will experience a rapid increase. The phenomenon is due to the large number of generations born in the early 2000 s who will turn 60 in 2060 . There are various triggers to this phenomenon, such as the tendency of Japanese to be reluctant to have a partner or get married, Japanese couples who are reluctant to have children, the workaholic culture which emphasizes personal interests rather than shared one, and the mindset of the 2000 generation that begins to shift from family towards becoming more individualized. Hence, these factors greatly influence the demographic formation of Japan.

Referring to the data on the number of elders who continue to increase, there are two potentials that will happen to Japan in the future. First, the number of the workforces will continue to shrink, and economic growth will slow down as a result. Second, the number of outbound will tend to decline with a population dominated by elders. However, according to Mak, Carlile, and Dai (2005), it is predicted that in 2025 , there will be 8.163 .000 or around $36,2 \%$ of the total Japanese outbound who are over 55 years old. This statement is in line with the opinion of Lim and McAleer (2005) that the number of visitors aged 50 or over is likely to become the largest share group of Japanese outbound travelers.
This prediction will be both a challenge and an opportunity for Indonesia to attract potential market groups which previously have never been considered seriously before. Moreover, there is a fact that, in 2020 , around $72 \%$ of wealth assets in Japan are held by retirees or those who aged over 55 years old. It is predicted that, in 2040, it will continue to increase by around 79\% (Statistics Bureau of Japan, 2019). It can be implied that the retiree age in Japan has a more stable economy compared to the productive age. Consequently, focusing on the Japanese silver age market segment is essential for Indonesian tourism to become a leading travel destination for the Japanese market. Private and state tourism stakeholders in Indonesia need to formulate major strategical changes to address this challenge.

The development of at least the careful selection of destinations intended to be marketed towards the silver age will significantly affect the future of promotion in the Japanese market. Several competing countries have taken this measure to attract Japanese travelers to visit, such as Malaysia, the Philippines, and Thailand (Sangpikul, 2008). These countries have emphasized the silver age travelers from Japan. A development, which is seriously worked on, makes these three countries the main destinations of several countries with high life expectancy, especially in Southeast Asia. Moreover, the development for destinations for silver age tourism also exists. For example, in Bali, the Perancak area of Jembrana Regency, Gerokgak in Buleleng Regency, Amed area in Karangasem Regency, Bedugul-Pancasari area in Tabanan, and Kintamani in Bangli Regency have developed destinations specially tailored for the silver age.

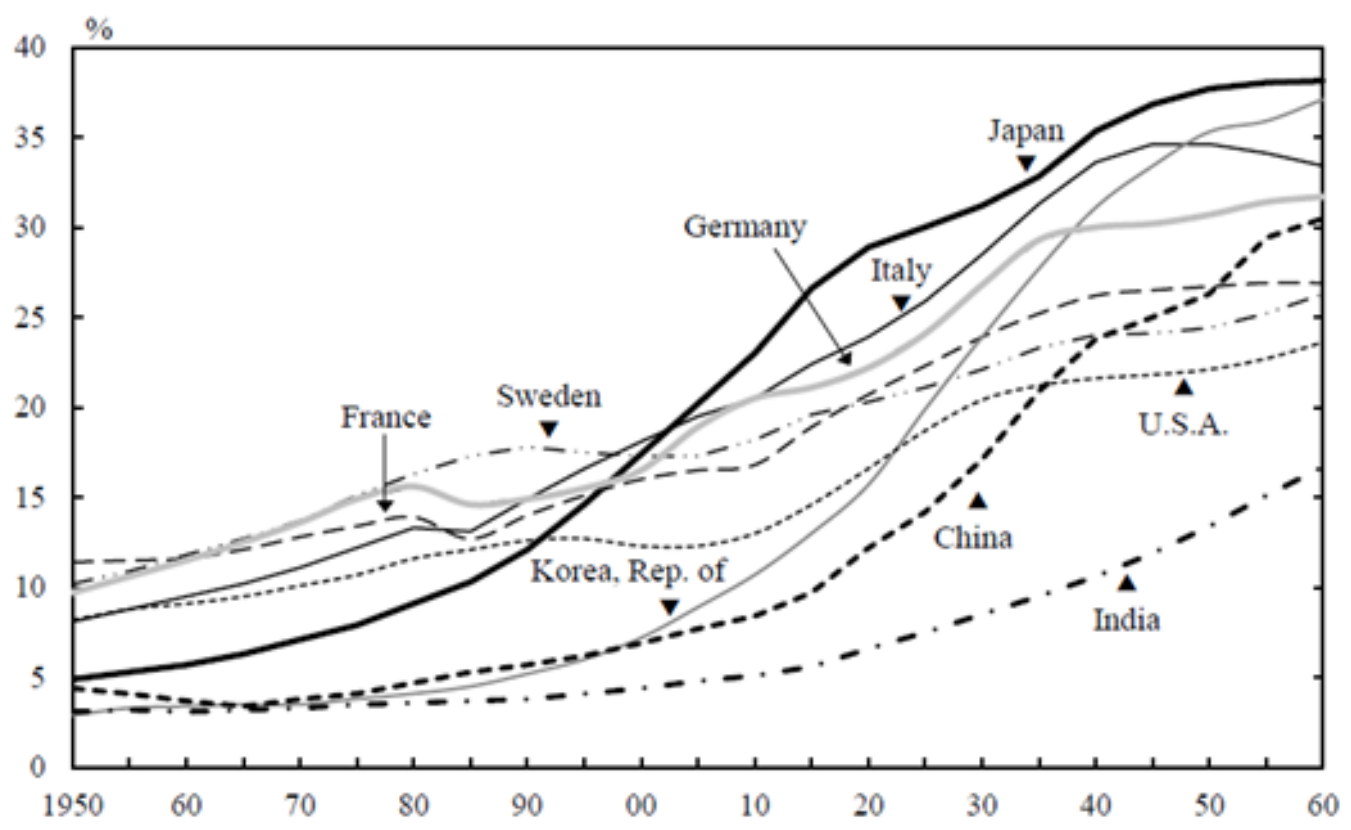

Figure 2 The Projected Population of Japan until 2060 (Source: Statistics Bureau of Japan, 2019) 
Moreover, around $45,07 \%$ of Japanese travelers seek leisure activities or relaxing holidays, and $39,80 \%$ of Japanese travelers come for Meeting, Incentive, Convention, Exhibition (MICE) purposes while visiting Indonesia (Kementerian Pariwisata dan Ekonomi Kreatif Republik Indonesia, 2019). The high number of MICE purposes is supported by comparing the arrival of Japanese tourists to Indonesia based on gender. Joshitabi or career working woman that is quite well established in Japan, now amounts to around 69,4\% (Kementerian Pariwisata dan Ekonomi Kreatif Republik Indonesia, 2019). The data are also supported by Lim and McAleer (2005). The growth of female travelers from Japan is higher than men.

Japanese female travelers enjoy shopping and culinary activities while traveling in Indonesia. That statement is supported by the data showing that the expenditure is for food $(43,4 \%)$, shopping for batik (27,8\%), and handicrafts (24\%) (Kementerian Pariwisata dan Ekonomi Kreatif Republik Indonesia, 2019). The data can be used as a basis in developing a tourism promotion strategy for the Japanese market. Utilizing the huge diversity in Indonesian culture is an added value in which competing countries do not have. For example, an extensive array of traditional food and unique traditional textiles products vary from one region to another which can only be found in Indonesia. Then, art craft or local goods intended for souvenirs for tourists have different characteristics from one another.

One of the shortcomings and weaknesses of Indonesia as a travel destination is that many tourism destinations do not have a complete and centralized shopping location. Hence, the prospective tourists, in this case, Joshitabi, have trouble getting souvenirs or gifts for their relatives or friends back in Japan. Bringing back some souvenirs or omiyage in Japanese culture is an important unwritten norm for Japanese travelers when returning to their home from a destination (Kim et al., 2011). This shortcoming will have a big impact on how much tourists spend over a destination. Various locations, which are a favorite location for shopping in various competing tourism countries, have centralized shopping facilities. Even these locations have become a tourism icon for the country. For example, the Orchard area in Singapore or the Petaling Jaya area in Malaysia. Indonesia should develop similar shopping tourism attractions in several regions. Thus, it will be easier for potential tourists, especially Joshitabi, to go shopping. The areas that have good potential to be developed into a shopping center are Bali and DKI Jakarta, according to Badan Pusat Statistik (2020). The data show that $49,6 \%$ and $39,5 \%$ of Japanese travelers enter Indonesia through Bali and Jakarta, respectively. Bali and Jakarta are the two main entrances for foreign tourists who come to Indonesia.

Furthermore, air transportation is an indispensable tourism element (Jayaprakash, 2016; Yusup et al., 2016). It provides the fastest link between tourist originations and their intended destinations
(Fageda, Suárez-Alemán, Serebrisky, \& Fioravanti, 2018; Fernández, Coto-Millán, \& Díaz-Medina, 2018; Li, Fu, Lei, Wang, \& Alday, 2020). Currently, more than $57 \%$ of international travelers reach their destination by air transportation (Air Transport Action Group, 2018). In addition, Indonesia has borders that are not only in the form of the land but also sea, which is both wide and reachable only by air or sea transport (Asthu, 2020). However, Indonesia relies heavily on air transportation modes to enter or leave its territory.

The distance between Indonesia (SoekarnoHatta Airport) and Japan (Haneda Airport) is 5.770 $\mathrm{km}$, or it takes approximately seven hours of a direct flight. Based on the statistics on the arrival of foreign tourists in 2019, Japanese travelers who entered through Ngurah Rai and Soekarno-Hatta airports were respectively $49,6 \%$ and $39,4 \%$. The remaining $7,51 \%$ entered through the seaport of the Riau Islands, located close to Singapore (Badan Pusat Statistik, 2020). Summing up, a total of $89 \%$ of Japanese travelers enter Indonesia using air transportation. So far, there are only five direct flight routes between Indonesia and Japan, as shown in Figure 3.

It indicates that aviation-related infrastructure is very important, including air connectivity. The development of air transportation and its relation to tourism is highly dependent on the business models of the two sectors. Commercial air transportation is also determined by passenger type, such as lowcost and charter flights (Fernández et al., 2018). Therefore, the business calculation is crucial in seeing opportunities to bring tourists to Indonesia by utilizing air connectivity.

The number of visits from each city in origin can be used as a reference to consider new openings or additional flight routes to maximize connectivity. In 2018 , the composition of Japan's population of $68,9 \%$ was concentrated in three prefectures (regions like provinces), namely Kanto Prefecture $(34,4 \%$ ) with Tokyo as the most populated city, Kinki Prefecture $(17,6 \%)$ with Osaka as the most populated city, and Chubu Prefecture (16,8\%) with the largest city of Aichi (Statistics Bureau of Japan, 2019). The two prefectures of Kanto and Kinki already have air connectivity to and from Indonesia. However, there is no connection for Chubu prefecture from and to Indonesia as of the writing of the research.

Based on the data presented, there is a big potential for increasing the number of Japanese travelers to Indonesia through Chubu prefecture. Chubu area has the third-highest population and economy in Japan, which can be proposed for air connectivity opening to unlock a new market. Opening new air connectivity for the Chubu area in Jakarta or Bali will help to increase the overall number of Japanese tourists' visits to Indonesia. Additionally, by the opening of Chubu to and from Indonesia, travelers from Japan who want to visit Indonesia will have additional options, apart from taking flights from Kanto or Kinki region. Japan has an excellent highspeed railway network which makes traveling from 


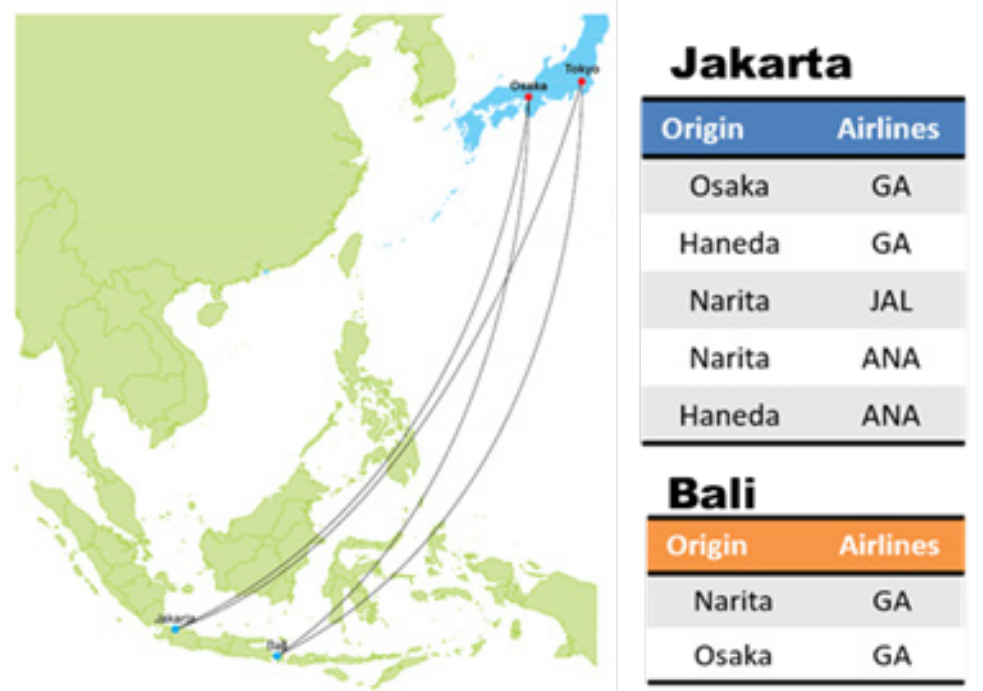

Figure 3 Indonesia - Japan Air Connectivity (Source: Skyscanner, 2020)

one city to another within a day possible. If one cannot get a flight ticket to travel to Indonesia from one city in Japan, he or she can take other options by flying from another city that has available flights to Indonesia by traveling there using the high-speed train.

Then, Asian people, who love to travel in groups, always prefer to communicate using their mother tongue. They are reluctant to use the widely used language of instruction, such as English and Mandarin. This situation makes Japanese travelers need special treatment, such as using language and signs in Japanese on public facilities, which many Japanese tourists visit. It is based on the characteristics of Japanese culture, which deeply instills introverted values so that a sense of comfort with the language and fellow Japanese becomes part of their daily life. It is expected that using Japanese markers and group travel, which are usually due to insecurities in using foreign languages, can be reduced.

One of the characteristics of Japan that is almost inherent in modern culture is the obsession with cleanliness, tidiness, and order. They are educated by instilling a love for cleanliness (Sangpikul, 2008). It is argued that the Japanese tourists really pay attention to cleanliness so that destinations that do not meet their standard of hygiene values will reduce their interest in a destination (Liu et al., 2019). It is a challenge in Indonesia. Changing the behavior of Indonesia's society is indeed quite a challenge, as evidenced by a large amount of waste and the behavior of disposing of garbage that is no longer in use in Indonesia. Therefore, the hygiene factor is something that must be addressed. In 2019, Travel \& Tourism Competitiveness Index (TTCI) reported that Indonesia's sanitation and hygiene score was relatively low $(4,5$ out of the highest score, 7$)$. Compared to the sanitation and hygiene scores of other Southeast Asian countries, Indonesia is still below the average 4,9 score (World Economic Forum, 2019b). The choice of destinations to be marketed is primarily to provide a 'clean' experience. In addition, Japanese tourists view health facilities as crucial. Hence, the locations must have 'very qualified' health facilities. It is necessary to pay attention to the existence of health facilities around the destination, such as the availability of clinics or hospitals which meet international standards. At least, improving and standardizing the hygiene and health facility at destinations can help to improve Japanese travelers' perception of the destinations and Indonesia as a whole.

The analysis of these findings may be used as an indicator to attract Japanese tourists to come to Indonesia. However, an understanding of market characteristics is needed to attract tourists so that what is done will be more directed and targeted. Moreover, the research analysis makes demographics the subject of study, and many findings can be further explored to attract the Japanese market, as stated by SinclairMaragh (2017). Culture represents the accumulation of behavioral patterns in society and different macroenvironment elements. All elements affect different behavioral patterns (Scupin, 2020).

\section{CONCLUSIONS}

Japan is one of the largest outbound source countries, and in the last five years, it has always occupied the top five contributors of international visitors to Indonesia. Hence, it is still a very potential tourism market and can be explored even further. Indonesia can take four strategic efforts to maximize the potential for the arrival of foreign tourists from Japan to Indonesia.

First, with the demographic structure of Japan that senior citizens tend to have a significant share, the direction of destination development and strategy 
efforts can be focused on attracting the silver age tourists. Characteristics such as leisure, long stay vacation, easy access to health facilities, and dedicated carers for senior citizens must be considered in preparing or selecting destinations related to the silver age group.

Second, there is Joshitabi or a career woman. The comparison of the number of arrivals between men and women is obvious, with a margin of almost $40 \%$. It makes career women a market share which must be considered. With the fondness of shopping for various handicrafts and culinary tours, Joshitabi requires different treatment compared to the silver age group. A selection of destinations that provide a quality shopping experience and a complete culinary center is needed to hook on this niche market.

Third, air connectivity is important in traveling, related to distance from origination and destinations. The connectivity between the two major cities in Japan and Indonesia seems to limit the movement of potential Japanese tourists who intend to visit Indonesia. Therefore, the opening of the route from Chubu as the third most populated prefecture in Japan is an opportunity that is worth considering. The flight route can be directed directly to Bali, as the main entry point for Japanese tourists to Indonesia to be more effective.

Fourth, the Japanese culture that must be seriously considered is the dependence of Japanese tourists on the use of their mother tongues and awareness of high hygiene standards. One of the introverted traits of Japanese tourists is their dependence on the use of their mother tongue anywhere. Their reluctance to use English is an obstacle that must be overcome. So, using the Japanese language in several markers to support tourism activities will significantly help Japanese travelers during their visit.

It is considered that the research can be a source of reference for decision-makers to determine what and who will be the main targets to be attracted to Indonesia. The system applied to foreign markets is still general and is not specialized based on scientific findings in the field. However, the research also has limitations. The research only analyzes demographic data before 2020. Therefore, the most recent data have not been analyzed. The data are beneficial in further research because there are other factors that will significantly influence the behavior of the Japanese market, such as the Covid-19 pandemic, which has changed many established habits and systems.

\section{REFERENCES}

Air Transport Action Group. (2018). Aviation benefits beyond borders. Retrieved from https://aviationbenefits.org/ media/166711/abbb18_full-report_web.pdf

Artal-Tur, A., Pallardó-López, V. J., \& Requena-Silvente, F. (2016). Examining the impact of visa restrictions on international tourist flows using panel data. Estudios de Economía, 43(2), 265-279. http://dx.doi.
org/10.4067/S0718-52862016000200005

Asthu, A. A. (2020). Pengembangan wilayah perbatasan Indonesia menggunakan pendekatan pariwisata. Sosioteknologi, 19(1), 75-91. https://doi.org/http:// dx.doi.org/10.5614\%2Fsostek.itbj.2020.19.1.6

Badan Pusat Statistik. (2019). Statistik kunjungan wisatawan mancanegara 2018. Retrieved from https://www.bps.go.id/publication/2019/08/28/ f2e676c8c2b7ae3346a28b88/statistik-kunjunganwisatawan-mancanegara-2018.html

Badan Pusat Statistik. (2020). Jumlah kunjungan wisman ke Indonesia Desember 2019 mencapai 1,38 juta kunjungan. Retrieved from https:/www.bps.go.id/ pressrelease/2020/02/03/1711/jumlah-kunjunganwisman-ke-indonesia-desember-2019-mencapai-138-juta-kunjungan-.html

Bank Indonesia. (2018). Edisi 73 - Mendulang devisa melalui pariwisata. Retrieved from https://www.bi.go. $\mathrm{id} / \mathrm{id} /$ publikasi/E-Magazine/Pages/GeraiInfo-73 Mendulang-Devisa-Melalui-Pariwisata.aspx

Battour, M., Hakimian, F., Ismail, M., \& Boğan, E. (2018). The perception of non-muslim tourists towards halal tourism: Evidence from Turkey and Malaysia. Journal of Islamic Marketing, 9(4), 823-840. https:// doi.org/10.1108/JIMA-07-2017-0072

Chhorn, T. (2017). On the investigation of factors efecting international tourist arrivals to the Cambodia market: A static and dynamic gravity approach. Southeast Asian Journal of Economics, 5(2), 115-138.

Dai, T., Hein, C., \& Zhang, T. (2019). Understanding how Amsterdam City tourism marketing addresses cruise tourists' motivations regarding culture. Tourism Management Perspectives, 29(January), 157-165. https://doi.org/10.1016/j.tmp.2018.12.001

Fageda, X., Suárez-Alemán, A., Serebrisky, T., \& Fioravanti, R. (2018). Air connectivity in remote regions: A comprehensive review of existing transport policies worldwide. Journal of Air Transport Management, 66(January), 65-75. https://doi.org/10.1016/j. jairtraman.2017.10.008

Fernández, J. A. S., Azevedo, P. S., Martín, J. M. M., \& Martín, J. A. R. (2020). Determinants of tourism destination competitiveness in the countries most visited by international tourists: Proposal of a synthetic index. Tourism Management Perspectives, 33(January), 1-13. https://doi.org/10.1016/j. tmp.2019.100582

Fernández, X. L., Coto-Millán, P., \& Díaz-Medina, B. (2018). The impact of tourism on airport efficiency: The Spanish case. Utilities Policy, 55(December), 52-58. https://doi.org/10.1016/j.jup.2018.09.002

Jayaprakash, K. (2016). Factors influencing the tourists to visit Udhagamandalam. International Journal of Management \& Social Science Research Review, 1(25), 40-44.

Kamata, H., \& Misui, Y. (2015). The difference of Japanese spa tourists motivation in weekends and weekdays. Procedia - Social and Behavioral Sciences, 175, 210218. https://doi.org/10.1016/j.sbspro.2015.01.1193

Kementerian Pariwisata dan Ekonomi Kreatif Republik Indonesia. (2019). Passenger exit survey 2016. 
Retrieved from https://kemenparekraf.go.id/ publikasi-passenger-exit-survey/Passenger-ExitSurvey-2016

Kim, J., Lee, C., \& Mjelde, J. W. (2018). Impact of economic policy on international tourism demand: The case of Abenomics. Current Issues in Tourism, 21(16), 1912-1929. https://doi.org/10.1080/1368350 0.2016 .1198307

Kim, S., Park, E., \& Lamb, D. (2019). Extraordinary or ordinary? Food tourism motivations of Japanese domestic noodle tourists. Tourism Management Perspectives, 29(January), 176-186. https://doi. org/10.1016/j.tmp.2019.01.001

Kim, S. S., Timothy, D. J., \& Hwang, J. (2011). Understanding Japanese tourists' shopping preferences using the Decision Tree Analysis method. Tourism Management, 32(3), 544-554. https://doi.org/10.1016/j.tourman.2010.04.008

Kumar, S., \& Dhir, A. (2020). Associations between travel and tourism competitiveness and culture. Journal of Destination Marketing and Management, 18(December), 1-11. https://doi.org/10.1016/j. jdmm.2020.100501

Li, L. B., Fu, X., Lei, Z., Wang, K., \& Alday, S. S. (2020). Quantifying market potential for sustainable air connectivity improvement - A counterfactual analysis based on augmented gravity model estimates. Research in Transportation Business and Management, 34(March), 1-13. https://doi. org/10.1016/j.rtbm.2019.100425

Lim, C., \& McAleer, M. (2005). Analyzing the behavioral trends in tourist arrivals from Japan to Australia. Journal of Travel Research, 43(4), 414-421. https:// doi.org/10.1177/0047287505274654

Liu, X., Li, J. J., \& Kim, W. G. (2017). The role of travel experience in the structural relationships among tourists' perceived image, satisfaction, and behavioral intentions. Tourism and Hospitality Research, 17(2), 135-146. https://doi. org/10.1177/1467358415610371

Liu, J., Pan, H., \& Zheng, S. (2019). Tourism development, environment and policies: Differences between domestic and international tourists. Sustainability, 11(5), 1-15. https://doi.org/10.3390/su11051390

Liu, J., Wang, C., Fang, S., \& Zhang, T. (2019). Scale development for tourist trust toward a tourism destination. Tourism Management Perspectives, 31(July), 383-397. https://doi.org/10.1016/j. tmp.2019.07.001

Mak, J., Carlile, L., \& Dai, S. (2005). Impact of population aging on Japanese international travel to 2025. Journal of Travel Research, 44(2), 151-162. https:// doi.org/10.1177/0047287505278993

Mariyono, J. (2017). Determinants of demand for foreign tourism in Indonesia. Jurnal Ekonomi Pembangunan, 18(1), 82-92. https://doi.org/10.23917/jep. v18i1.2042

Marrocu, E., Paci, R., \& Zara, A. (2015). Micro-economic determinants of tourist expenditure: A quantile regression approach. Tourism Management, 50(October), 13-30. https://doi.org/10.1016/j. tourman.2015.01.006

Mendola, D., \& Volo, S. (2017). Building composite indicators in tourism studies: Measurements and applications in tourism destination competitiveness. Tourism Management, 59(April), 541-553. https:// doi.org/10.1016/j.tourman.2016.08.011

Mishra, S. S., \& Bansal, V. (2017). Role of sourcedestination proximity in international inbound tourist arrival: Empirical evidences from India. Asia Pacific Journal of Tourism Research, 22(5), 540553. https://doi.org/10.1080/10941665.2017.12871 07

Moon, H., \& Han, H. (2019). Tourist experience quality and loyalty to an island destination: The moderating impact of destination image. Journal of Travel \& Tourism Marketing, 36(1), 43-59. https://doi.org/10 $.1080 / 10548408.2018 .1494083$

Mylonopoulos, D., Moira, P., \& Kikilia, A. (2016). The travel advice as an inhibiting factor of tourist movement. TIMS. Acta, 10(1), 13-26. https://doi. org/10.5937/timsact10-9902

Ob, E., \& Mp, D. (2018). The influence of visa restrictions on the choice of travel destination among the academic and senior staff of Michael Okpara University of Agriculture, Umudike. Journal of Tourism \& Hospitality, 7(2), 1-8. https://doi.org/10.4172/21670269.1000351

Sangpikul, A. (2008). Travel motivations of Japanese senior travellers to Thailand. International Journal of Tourism Research, 10(1), 81-94. https://doi. org/10.1002/jtr.643

Scupin, R. (2020). Cultural anthropology: A global perspective. SAGE Publications.

Sinclair-Maragh, G. (2017). Demographic analysis of residents' support for tourism development in Jamaica. Journal of Destination Marketing \& Management, 6(1), 5-12. https://doi.org/10.1016/j. jdmm.2016.03.005

Sinclair-Maragh, G., Gursoy, D., \& Vieregge, M. (2015). Residents' perceptions toward tourism development: A factor-cluster approach. Journal of Destination Marketing \& Management, 4(1), 36-45. https://doi. org/10.1016/j.jdmm.2014.10.001

Skyscanner. (2020). Cheap flights from Japan to Indonesia at Skyscanner. Retrieved from https://www.skyscanner.net/transport/flights/jp/ $\mathrm{id} /$ ?adults $=1 \&$ children $=0 \&$ adultsv $2=1 \&$ childrenv $2=\& \mathrm{infants}=0 \& \mathrm{c}$ a b i n 1 a s s $=$ e c o n o m y \& r t n $=1 \&$ preferdirect $s=$ false \&preferflexible $=$ false\&outboun daltsenabled $=$ false\&inboundaltsenabled $=$ false $\&$ ref $=$ home

Statistics Bureau of Japan. (2019). Statistical handbook of Japan. Retrieved from https://www.stat.go.jp/ english/data/handbook/pdf/2019all.pdf

Subadra, I. N., Sutapa, I. K., Artana, I. W. A., Yuni, L. K. H. K., \& Sudiarta, M. (2019). Investigating push and pull factors of tourists visiting Bali as a world tourism destination. International Journal of Multidisciplinary Educational Research, 8(8), 253269. https://doi.org/10.6084/m9.figshare.9916247

Sukirman, O. (2017). Apakah anggaran pemasaran 
pariwisata pemerintah efektif dalam meningkatkan jumlah kunjungan wisatawan? THE Journal: Tourism and Hospitality Essentials Journal, 7(2), 121-128. https://doi.org/10.17509/thej.v7i2.9018

The World Bank. (2020). GDP (Current US\$). Retrieved from https://data.worldbank.org/indicator/NY.GDP. MKTP.CD

Utama, I. G. B. R. (2016). Destination image of Bali based on the push motivational factors, identity and destination creations in the perspective of foreign senior tourist. Jurnal Manajemen dan Kewirausahaan (Journal of Management and Entrepreneurship), 18(1), 16-24.

Williams, P., Soutar, G., Ashill, N. J., \& Naumann, E. (2017). Value drivers and adventure tourism: A comparative analysis of Japanese and Western consumers. Journal of Service Theory and Practice, 27(1), 102122. https://doi.org/10.1108/JSTP-05-2015-0116

World Economic Forum. (2019a). Elderly people make up a third of Japan's population - and it's reshaping the country. Retrieved from https://www.weforum.org/ agenda/2019/09/elderly-oldest-population-worldjapan/
World Economic Forum. (2019b). The travel \& tourism competitiveness report 2019. Retrieved from https:// www.weforum.org/reports/the-travel-tourismcompetitiveness-report-2019

Yeung, M. W., Kim, S., \& Schuckert, M. (2016). Japanese tourists to Hong Kong: Their preferences, behavior, and image perception. Journal of Travel \& Tourism Marketing, 33(5), 730-741. https://doi.org/10.1080/ 10548408.2016.1167388

Yu, J. Y., \& Ko, T. G. (2012). A cross-cultural study of perceptions of medical tourism among Chinese, Japanese and Korean tourists in Korea. Tourism Management, 33(1), 80-88. https://doi.org/10.1016/j. tourman.2011.02.002

Yusup, M. F., Kanyan, A., Kasuma, J., Kamaruddin, H., \& Adlin, J. (2016). Determinants of factors and the growth of tourism industry in Langkawi Island. Journal of Scientific Research and Development, 3(2), 13-20.

Zellatifanny, C. M., \& Mudjiyanto, B. (2018). Tipe penelitian deskripsi dalam ilmu komunikasi. Diakom: Jurnal Media dan Komunikasi, 1(2), 83-90. 